\title{
The Cooperative Learning Model of the Make a Match Method to Increase the Learning Output
}

\section{Fransisca Dita Damayanti}

\author{
SD Negeri Magelang 6 \\ fransiscaditadamayanti@gmail.com
}

\section{Article History}

received 3/12/2020

\begin{abstract}
Learning is a process which built by teacher to increase student's creative thingking, also can improve the ability of construct new knowledge. Learning outcome is one of important things to consider in learning. The learning outcomes can be formed as verbal information, intellectual skills, cognitive strategies, motoric skills, and attitudes. To get maksimum learning outcomes, the teacher must be good at designing learning by using a variety of learning models which combined by appropriate media. The cooperative learning model of the make a mach method packaged in the form of a game where students work in groups to match questions and answers in the form of cards with certain time limit. As the result we know that cooperative learning model of the make a mach method can increase the student's learning outcomes, activeness, and cooperation. The application of this method suitable to be applied in various sciences and levels.
\end{abstract}

Keywords: learning outcomes, cooperative, make a match

\begin{abstract}
Abstrak
Pembelajaran adalah proses belajar yang dibangun guru meningkatkan kemampuan berpikir peserta didik, serta dapat meningkatkan kemampuan mengkonstruksi pengetahuan baru. Hasil belajar merupakan salah satu hal penting yang diperhatikan dalam pembelajaran. Adapun hasil belajar dapat berupa informasi verbal, keterampilan intelektual, strategi kognitif, keterampilan motorik, serta sikap. Untuk mendapatkan hasil belajar yang optimal, guru harus pandai merancang pembelajaran dengan menggunakan berbagai variasi model pembelajaran yang dipadukan dengan media yang sesuai. Model pembelajaran kooperatif metode make a mach merupakan model pembelajaran yang dikemas dalam bentuk permainan di mana siswa bekerja dalam kelompok untuk mencocokkan pertanyaan dan jawaban dalam bentuk kartu dengan batasan waktu tertentu Menurut hasil kajian didapatkan data bahwa melalui penerapan model pembelajaran kooperatif metode make a mach dapat meningkatkan hasil belajar peserta didik, keaktifan, dan gotong royong. Penerapan metode ini cocok untuk diterapkan dalam berbagai bidang ilmu dan tingkatan.
\end{abstract}

Kata kunci: hasil belajar, kooperatif, make a match

Social, Humanities, and Education Studies (SHEs): Conference Series https://jurnal.uns.ac.id/shes

p-ISSN 2620-9284 e-ISSN 2620-9292 


\section{PENDAHULUAN}

Pembelajaran adalah proses belajar yang dibangun guru untuk mengembangkan kreativitas berpikir yang dapat meningkatkan kemampuan berpikir peserta didik, serta dapat meningkatkan kemampuan mengkonstruksi pengetahuan baru sebagai upaya peningkatan penguasaan yang baik terhadap materi pelajaran (Pratiwi: 2018: 37). Hasil belajar merupakan salah satu hal penting yang diperhatikan dalam pembelajaran. Menurut Suprijono (2012: 5) hasil belajar merupakan pola-pola perbuatan, nilai-nilai, pengertian-pengertian, sikap-sikap, dan keterampilan. Adapun hasil belajar dapat berupa informasi verbal, keterampilan intelektual, strategi kognitif, keterampilan motorik, serta sikap. Untuk mendapatkan hasil belajar yang optimal, guru harus pandai merancang pembelajaran dengan menggunakan berbagai variasi model pembelajaran yang dipadukan dengan media yang sesuai.

Ciri-ciri model pembelajaran yang baik menurut Fathurrohman (2014) adalah: 1) adanya keterlibatan intelektual emosional peserta didik melalui kegiatan, 2) adanya keikutsertaan peserta didik secara aktif dan kreatif selama pelaksanaan model pembelajaran, 3) guru bertindak sebagai fasilitator, koordinator, mediator dan motivator kegiatan belajar, 4) menggunakan berbagai metode, alat dan media pembelajaran.

Hal yang perlu diperhatikan dalam memilih atau menentukan model pembelajaran adalah kondisi Kompetensi Dasar (KD), tujuan yang akan dicapai dalam pengajaran, sifat dari materi yang akan diajarkan, dan tingkat kemampuan peserta didik. Di samping itu, setiap model pembelajaran mempunyai tahap-tahap (sintaks) yang dapat dilakukan siswa dengan bimbingan guru. Pelaksanaan pembelajaran dengan pendekatan saintifik sebagaimana yang diterapkan pada kurikulum 2013, sebaiknya dipadukan secara sinkron dengan langkah/tahapan kerja (syntax) model pembelajaran. Salah satu model yang seringkali dipilih oleh guru adalah model pembelajaran kooperatif.

Menurut Suprijono (2012: 65) sintak model pembelajaran kooperatif terdiri atas enam fase yang dapat diuraikan pada tabel berikut.

Tabel 1. Sintak Model Pembelajaran Kooperatif

\begin{tabular}{|c|c|}
\hline FASE-FASE & PERILAKU GURU \\
\hline $\begin{array}{l}\text { Fase 1: Present goals and set } \\
\text { Menyampaikan tujuan dan memp } \\
\text { siapkan peserta didik }\end{array}$ & $\begin{array}{l}\text { lenjelaskan tujuan pembelajaran dan } \\
\text { empersiapkan peserta didik siap belajar }\end{array}$ \\
\hline $\begin{array}{l}\text { Fase 2: Present information } \\
\text { Menyajikan informasi }\end{array}$ & $\begin{array}{l}\text { Mempresentasikan informasi } \\
\text { peserta didik secara verbal }\end{array}$ \\
\hline $\begin{array}{l}\text { Fase 3: Organize students into learning } \\
\text { teams }\end{array}$ & $\begin{array}{l}\text { an penjelasan kepada } p \\
\text { ang tata cara pembentuk }\end{array}$ \\
\hline $\begin{array}{l}\text { organisir peserta didik ke dalam tim- } \\
\text { lajar }\end{array}$ & $\begin{array}{l}\text { belajar dan membantu kelompok } \\
\text { melakukan transisi yang efisien }\end{array}$ \\
\hline $\begin{array}{l}\text { Fase 4: Assist team work and study } \\
\text { Membantu kerja tim dan belajar }\end{array}$ & $\begin{array}{l}\text { tu tim-tim belajar selama peserta } \\
\text { ngeriakan tugasnya }\end{array}$ \\
\hline $\begin{array}{l}\text { Fase 5: Test on the materials } \\
\text { Mengevaluasi }\end{array}$ & $\begin{array}{l}\text { Menguji pengetahuan peserta didik } \\
\text { mengenai berbagai materi pembelajaran } \\
\text { atau kelompok-kelompok mempresentasi- } \\
\text { kan hasil kerjanya }\end{array}$ \\
\hline $\begin{array}{l}\text { Fase 6: Provide recognition } \\
\text { Memberikan pengakuan } \\
\text { hargaan }\end{array}$ & $\begin{array}{l}\text { Mempersiapkan cara untuk mengakui } \\
\text { usaha dan prestasi individu maupun } \\
\text { kelompok }\end{array}$ \\
\hline
\end{tabular}

Lingkungan belajar dan sistem pengelolaan pembelajaran kooperatif harus: 1) memberikan kesempatan terjadinya belajar berdemokrasi; 2) meningkatkan penghargaan peserta didik pada pembelajaran akademik dan mengubah norma-norma 
yang terkait dengan prestasi; 3) mempersiapkan peserta didik belajar mengenai kolaborasi dan berbagai keterampilan sosial melalui peran aktif peserta didik dalam kelompok-kelompok kecil; 4) memberi peluang terjadinya proses partipasi aktif peserta didik dalam belajar dan terjadinya dialog interaktif; 5) menciptakan iklim sosio emosional yang positif; 6) memfasilitasi terjadinya learning to live together; 7) menumbuhkan produktivitas dalam kelompok; 8) mengubah peran guru dari centre stage performance menjadi koreografer kegiatan kelompok; 9) menumbuhkan kesadaran para peserta didik arti penting aspek sosial dalam individunya.

Model pembelajaran kooperatif adalah sebuah cara atau strategi dalam pembelajaran yang menempatkan peserta didik sebagai pusat dari pembelajaran (student center) ke dalam beberapa kelompok sehingga peserta didik dibebaskan untuk mengeksplorasi ilmu atau pengetahuannya di mana dalam proses pembelajarannya lebih menekankan pada sebuah kerja sama antar peserta didik dalam kelompok (Juhji: 2017, 11). Sadker (Huda, 2011: 66) menjabarkan beberapa manfaat pembelajaran kooperatif. Selain itu, meningkatkan keterampilan kognitif dan afektif siswa, pembelajaran kooperatif juga memberikan manfaat-manfaat besar lain seperti berikut ini.

a. siswa yang diajari dengan dan dalam struktur-struktur kooperatif akan memperoleh hasil pembelajaran yang lebih tinggi;

b. siswa yang berpartisipasi dalam pembelajaran kooperatif akan memiliki sikap hargadiri yang lebih tinggi dan motivasi yang lebih besar untuk belajar;

c. dengan pembelajaran kooperatif, siswa menjadi lebih peduli pada temantemannya, dan di antara mereka akan terbangun rasa ketergantungan yang positif (interdependensi positif) untuk proses belajar mereka nanti;

d. pembelajaran kooperatif meningkatkan rasa penerimaan siswa terhadap temantemannya yang berasal dari latar belakang ras dan etnik yang berbeda-beda.

Pada pembelajaran kooperatif banyak sekali metode yang dikembangkan. Beberapa di antaranya adalah two stay two stray, numbered head together, jigsaw, make a mach, bamboo dancing. Make a mach merupakan salah satu metode yang dikembangkan di mana peserta didik harus bekerja sama dalam kelompok untuk berdiskusi dalam memasangkan kartu pertanyaan dengan jawaban yang sesuai.

Berdasarkan uraian di atas rumusan penelitian ini yaitu: (1) Bagaimana konsep model pembelajaran kooperatif metode make a mach? (2) Bagaimana hubungan model pembelajaran kooperatif metode make a mach dapat meningkatkan hasil belajar?

\section{HASIL DAN PEMBAHASAN \\ A. Konsep Model Pembelajaran Kooperatif Metode Make a mach}

Model pembelajaran kooperatif metode make a mach dikembangkan oleh Lorna Curran pada tahun 1994. Model pembelajaran kooperatif metode make a mach merupakan model pembelajaran mencari pasangan antara kelompok pembawa kartu soal dengan kelompok pembawa kartu jawaban setelah mencocokkan kartunya sebelum batas waktu yang ditentukan maka diberi poin. Model ini dapat menumbuhkan kreativitas berpikir siswa sebab melalui pencocokkan pertanyaan dan jawaban akan tumbuh tersendirinya (Istarani, 2012).

Sejalan dengan pendapat tersebut Huda (2011) berpendapat bahwa model pembelajaran ini berupa sebuah permainan yang dilakukan siswa untuk mencari pasangan sambil belajar suatu konsep pemahaman dan topik pembelajaran dalam suasana bermain yang menyenangkan serta dapat diterapkan untuk semua mata pelajaran dan tingkatan kelas. Lestari dan Yudhanegara (2015: 75) menambahkan bahwa "make a mach merupakan model pembelajaran yang digunakan untuk memberikan konsep pemahaman kepada siswa serta dapat digunakan untuk mengetahui sejauh mana pengetahuan dan kemampuan siswa dari materi tersebut". 
Dari beberapa pendapat di atas dapat disimpulkan bahwa model pembelajaran kooperatif metode make a mach merupakan model pembelajaran yang dikemas dalam bentuk permainan di mana siswa bekerja dalam kelompok untuk mencocokkan pertanyaan dan jawaban dalam bentuk kartu dengan batasan waktu tertentu. Tujuan dari model pembelajaran ini adalah untuk mendapatkan konsep pemahaman. Adapun unsur penting dalam metode pembelajaran ini adalah kelompok dan kartu yang terdiri atas kartu pertanyaan dan kartu jawaban.

Huda (2013: 251) mengatakan bahwa tujuan model pembelajaran kooperatif metode make a mach yaitu untuk : (1) pendalaman materi ; (2) penggalian materi ; dan (3) sebagai selingan. Adapun persiapan yang harus dilakukan oleh guru sebelum proses pembelajaran berlangsung yaitu:

1) membuat beberapa pertanyan sesuai dengan materi yang dipelajari (jumlah tergantung pada tujuan pembelajaran) kemudian menulisnya dalam kartu-kartu pertanyaan;

2) membuat kunci jawaban dari pertanyaan-pertanyaan yang telah dibuat dan menulisnya dalam kartu-kartu jawaban; (akan lebih baik kartu jawaban dan kartu pertanyaan berbeda warna)

3) membuat aturan yang berisi penghargaan bagi siswa yang berhasil dan sansi bagi siswa yang gagal;

4) menyediakan lembar untuk mencatat pasangan-pasangan yang berhasil sekaligus untuk pensekoran presentasi.

Secara lebih rinci Lestari dan Yudhanegara (2015: 75) menyatakan langkahlangkah pembelajaran model kooperatif metode make a mach sebagai berikut:

1) guru menyiapkan beberapa kartu yang berisi beberapa konsep atau topik yang cocok untuk sesi review, satu bagian kartu soal dan bagian lainnya kartu jawaban;

2) setiap siswa mendapat satu kartu;

3) setiap siswa memikirkan jawaban/soal dari kartu yang dipegang;

4) setiap siswa mencari pasangan yang mempunyai kartu yang cocok dengan kartu (soal jawaban);

5) setiap siswa yang dapat mencocokan kartunya sebelum batas waktu diberi poin;

6) setelah satu babak, kartu dikocok lagi agar tiap peserta didik mendapat kartu yang berbeda dari sebelumnya, demikian seterusnya;

7) kesimpulan/penutup.

Model pembelajaran kooperatif metode make a mach tentunya memiliki kelebihan dan kelemahan. Adapun kelebihan model ini menurut Shoimin (2016) antara lain suasana kegembiraan akan tumbuh dalam proses pembelajaran, kerjasama antarsesama siswa terwujud dengan dinamis, dan munculnya dinamika gotong-royong yang merata di seluruh siswa. Istarani (2012) juga menambahkan bahwa kelebihan dari metode ini yaitu ; (1) siswa terlibat langsung dalam menjawab soal yang disampaikan kepadanya melalui kartu, (2) meningkatkan kreativitas belajar siswa, (3) menghindari kejenuhan siswa dalam mengikuti proses belajar mengajar, (4) dapat menumbuhkan kreativitas berfikir siswa, sebab melalui pencocokkan pertanyaan dan jawaban akan tumbuh tersendirinya, (5) pembelajaran lebih menyenangkan karena melibatkan media pembelajaran yang digunakan guru. Sehingga dapat diketahui bahwa model pembelajaran kooperatif metode make a mach tidak hanya mengembangkan siswa pada aspek kognitif tetapi juga pada aspek psikomotorik dan afektif. Hal ini selaras dengan tujuan kurikulum 2013 yang tidak hanya menuntut pengembangan kognitif sebagai hasil dari proses belajar melainkan juga berimbang pada aspek afektif dan psikomotorik.

Sedangkan kelemahannya, menurut Istarani (2012) adalah ; (1) sulit bagi guru mempersiapkan kartu-kartu yang baik dan bagus, (2) sulit mengatur ritme atau jalannya proses pembelajaran, (3) siswa kurang memahami makna pembelajaran yang ingin disampaikan karena merasa hanya sekedar permainan saja, (4) sulit untuk 
mengkonsentrasikan anak. Adapun Utami (2016: 4) menambahkan kelemahan dari metode ini adalah banyak waktu yang terbuang jika pembelajaran tidak dipersiapkan dengan baik, ada kemungkinan siswa tidak mau berpasangan dengan teman lawan jenis, siswa akan cenderung ramai dan dapat mengganggu kenyamanan kelas lain, serta metode ini kurang efektif jika ditempatkan pada kelas yang memiliki siswa banyak dan ruangan yang terbatas. Jadi dapat diketahui bahwa meskipun metode ini mengemas pembelajaran ke dalam bentuk yang lebih menyenangkan, perlu peranan guru dalam mengarahkan aktivitas siswa.

\section{B. Hubungan Model Pembelajaran Kooperatif Metode Make a mach Dapat Meningkatkan Hasil Belajar}

Menurut Nurhidayah, dkk (2017) melalui penerapan metode make a mach didapatkan hasil berupa peningkatan hasil belajar peserta didik kelas IV-A SDN Sindang II Kecamatan Sumedang Utara, Kabupaten Sumedang pada materi keberagaman suku bangsa dan budaya. Dari penelitian tersebut didapatkan data yang persentase pencapaian pada siklus I 7 (35\%) orang siswa tuntas, siklus II $12(60 \%)$ orang siswa tuntas, dan pada siklus III 17 (85\%) orang siswa tuntas. Selain itu pembelajaran dengan metode ini juga berdampak positif pada aktivitas peserta didik dalam aspek yang diamati yaitu keaktifan siswa, kerjasama siswa, dan kedisiplinan siswa.

Sejalan dengan penelitian tersebut Deschuri (2016) membuktikan bahwa penggunaan model pembelajaran kooperatif teknik make a mach dengan media kartu klop dapat meningkatkan hasil belajar peserta didik kelas V SDN Sindang III Kecamatan Sumedang Utara Kabupaten Sumedang pada materi kenampakan alam dan buatan wilayah Indonesia. Hal ini didukung dengan data penelitian yang menunjukkan bahwa tindakan pada siklus I hasil tes belajar peserta didik yang dapat mencapai ketuntasan sebanyak 12 peserta didik, pada siklus II meningkat menjadi 17peserta didik, dan pada siklus III menjadi 20 peserta didik atau 90\%. Hal ini menunjukan bahwa hasil belajar siswa telah mencapai target yang diharapkan yaitu $85 \%$.

Sirait (2013) dalam jurnal yang berjudul "Pengaruh Model Pembelajaran Kooperatif Tipe Make a mach terhadap Hasil Belajar Siswa" dengan subjek penelitian peserta didik kelas VIII SMP Swasta Budi Agung Medan mengemukakan bahwa hasil belajar peserta didik yang diajarkan dengan model pembelajaran kooperatif tipe make a mach lebih tinggi daripada hasil belajar peserta didik yang diajarkan dengan model pembelajaran langsung, karena pada model pembelajaran kooperatif tipe make a mach memberikan kesempatan kepada peserta didik untuk saling memberikan pendapat atau ide yang mereka miliki. Dengan adanya sumbangan pemikiran dari peserta didik lainnya serta bimbingan dari peneliti, maka pengetahuan peserta didik akan bertambah. Selain itu, dengan adanya pengelompokkan peserta didik secara heterogen dan pemberian penghargaan kelompok pada model pembelajaran kooperatif tipe make a mach, seluruh peserta didik berusaha maksimal dalam kelompoknya untuk memahami dan menguasai materi yang dipelajari.

Mikran, dkk (2014) menyampaikan bahwa dari hasil dan analisis data penelitian penerapan model pembelajaran kooperatif tipe make a mach dapat meningkatkan hasil belajar fisika siswa kelas VIIA SMP Negeri 1 Tomini pada konsep gerak. Hal ini didukung data yang menunjukkan bahwa hasil belajar peserta didik pada siklus I diperoleh nilai ketuntasan belajar klasikal sebesar $72 \%$ dan daya serap klasikal sebesar $72 \%$. Sedangkan pada hasil belajar peserta didik siklus II diperoleh nilai ketuntasan belajar klasikal sebesar $94 \%$ dan daya serap klasikal sebesar $82 \%$.

Pratiwi (2018) juga membuktikan bahwa berdasarkan hasil penerapan praktik di lapangan, ternyata metode pembelajaran Make a mach mempunyai beberapa kelebihan, diantaranya metode pembelajaran tersebut mampu menciptakan suasana 
belajar yang aktif dan menyenangkan, materi pembelajaran yang disampaikan menjadi lebih menarik perhatian peserta didik pada mata pelajaran IPA sehingga mampu meningkatkan hasil belajar peserta didik mencapai taraf ketuntasan belajar secara klasikal 87,50\%, kerjasama antar sesama peserta didik juga dapat terwujud dengan dinamis, serta munculnya dinamika gotong-royong yang merata di seluruh peserta didik.

Dari berbagai hasil penelitian di atas maka dapat diketahui bahwa melalui penerapan model pembelajaran kooperatif metode make a mach dapat meningkatkan hasil belajar siswa. Adapun penerapan metode ini cocok untuk diterapkan dalam berbagai bidang ilmu dan tingkatan. Melalui penerapan metode make a mach, keaktifan dan kerja sama peserta didik pun juga terbentuk. Seluruh peserta didik akan berusaha maksimal dalam kelompoknya untuk memahami dan menguasai materi yang dipelajari karena mereka tentunya termotivasi untuk mendapatkan poin setinggi mungkin.

\section{SIMPULAN}

Sesuai dengan rumusan masalah dan pembahasan, dapat diambil simpulan bahwa: (1) model pembelajaran kooperatif metode make a match merupakan model pembelajaran yang dikemas dalam bentuk permainan di mana siswa bekerja dalam kelompok untuk mencocokkan pertanyaan dan jawaban dalam bentuk kartu dengan batasan waktu tertentu, (2) melalui penerapan model pembelajaran kooperatif metode make a match dapat meningkatkan hasil belajar siswa, keaktifan, dan gotong royong. Penerapan metode ini cocok untuk diterapkan dalam berbagai bidang ilmu dan tingkatan. Akan tetapi perlu diperhatikan bahwa dalam penerapan metode make a match jika pembelajaran tidak dipersiapkan dengan baik banyak waktu yang terbuang, ada kemungkinan siswa tidak mau berpasangan dengan teman lawan jenis, siswa akan cenderung ramai dan dapat mengganggu kenyamanan kelas lain, serta metode ini kurang efektif jika ditempatkan pada kelas yang memiliki siswa banyak dan ruangan yang terbatas sehingga kesiapan dan peran guru cukup besar dalam penyajian pembelajaran.

\section{DAFTAR PUSTAKA}

Deschuri, Cani. (2016). Penerapan Model Kooperatif Teknik Make A Match dengan Media Kartu Klop untuk Meningkatkan Hasil Belajar Siswa pada Materi Kenampakan Alam dan Buatan. Jurnal Pena IImiah, 1(1), 361-370.

Fathurrohman. (2014). Model-model Pembelajaran Inovatif. Yogyakarta: Ar-Ruzz Media.

Huda, Miftahul. (2011). Cooperative Learning. Yogyakarta: Pustaka Pelajar.

Huda, Miftahul. (2013). Model-model Pengajaran dan Pembelajaran. Yogyakarta: Pustaka Pelajar.

Istarani. (2012). 58 Model Pembelajaran Inovatif. Medan: Media Persada.

Juhji. (2017). Model Pembelajaran Kooperatif Tipe Make A Match dalam Pembelajaran IPA. Primary, 9(1), 9-16.

Lestari dan Yudhanegara, Wahyudin. (2015). Penelitian Pendidikan Matematika. Bandung: PT. Refika Aditama.

Mikran, dkk. (2014). Penerapan Model Pembelajaran Kooperatif Make A Match untuk Meningkatkan Hasil Belajar Siswa Kelas VIIA SMP Negeri 1 Tomini pada Konsep Gerak.

Nurhidayah, Rina Suryati, dkk. (2017). Penerapan Model Pembelajaran Kooperatif Tipe Make A Match untuk Meningkatkan Hasil Belajar Siswa pada Materi Keragaman Suku Bangsa dan Budaya. Jurnal Pena Ilmiah, 2(1), 2051-2060. Jurnal Pendidikan Fisika Tadulako, 2(2), 9-16. 
Pratiwi, Rina Hidayati. (2018). Metode Pembelajaran "Make A Match" dan Pengaruhnya Terhadap Hasil Belajar IPA. Florea, 5(1), 37-43.

Shoimin, Aris. (2016). 68 Model Pembelajaran Inovatif dalam Kurikulum 2013. Yogyakarta: Ar-Ruzz Media.

Sirait, Makmur dan Putri adilah Noer. (2013). Pengaruh Model Pembelajaran Kooperatif Tipe Make A Match terhadap Hasil Belajar Siswa. Jurnal INPAFI, 1(3), 252-259. 